\title{
Violence and insecurity in urban space: an analytical approach based on the ecological framework for violence
}

\author{
Violencia e inseguridad en el espacio urbano: un enfoque \\ analítico basado en el marco ecológico para la violencia
}

\author{
Natalia Garcia-Cervantes ${ }^{1}$ \\ Universidad de Guanajuato, México \\ Univeristy of Manchester, United Kingdom
}

\begin{abstract}
Violence and insecurity have become pervasive in urban areas, particularly in Latin America, where this phenomenon represents an obstacle to development. Seeking to contribute to a more nuanced understanding of urban violence and insecurity, this article presents an analytical framework to organize and understand the different levels of risk factors interacting for the appearance of violence in urban areas. Based on the case study of Culiacán, Sinaloa (Mexico), the article presents an analysis of the interrelated nature of violence, different manifestations and risk factors leading to its proliferation, with a focus on urban space. Although the causality of violence is difficult to pinpoint, this framework allows not only to consider violence in a more structured way, but also to appraise the relationships between these phenomena at different levels of risk factors.
\end{abstract}

Keywords: Urban violence; Insecurity; Planning; Urban space; Ecological framework.

\section{Resumen}

La violencia y la inseguridad se han generalizado en las zonas urbanas, particularmente en América Latina, donde este fenómeno representa un obstáculo para el desarrollo. Con el objetivo de contribuir a una comprensión más matizada de la violencia urbana y la inseguridad, este artículo presenta un marco analítico para organizar y comprender los diferentes niveles de factores de riesgo

1 PhD Development Policy Management, by the Univeristy of Manchester, United Kingdom, Postdoctoral by Universidad de Guanajuato: División de Arquitectura, Arte y Diseño, Av Juarez No. 77, Zona Centro, Guanajuato, México. Email: natgcervantes@gmail.com. (DD https://orcid.org/0000-0002-9909-1496 
que interactúan para la aparición de violencia en zonas urbanas. Basado en el estudio de caso de Culiacán, Sinaloa, el artículo presenta un análisis de la naturaleza interrelacionada de la violencia, las diferentes manifestaciones y los factores de riesgo que conducen a su proliferación, con un enfoque en el espacio urbano. Si bien la causalidad de la violencia es difícil de precisar, este marco permite no solo considerar la violencia de una manera más estructurada, sino también considerar las relaciones entre estos fenómenos en diferentes niveles de factores de riesgo.

Palabras clave: Violencia urbana, inseguridad, planificación, espacio urbano, marco ecológico

\section{Introduction}

Urban violence and insecurity are a daily reality for many people around the world, particularly in the context of Latin America. Some studies have suggested the region is the most violent in the world (Buvinic et al., 1999; Imbusch et al., 2011; Latinobarometro, 2010; UNODC, 2013). For millions of people in Latin America, urban violence represents an obstacle for development (Buvinic and Morrison, 1999; Winton, 2004), and according to the NGO Seguridad, Justicia y Paz (2016), in 2015, 41 out of the world's 50 most violent cities were in Latin America. The region alone accounts for one third of global homicides, with just eight per cent of the world's population (Seguridad, Justicia y Paz, 2016). The causes of violence have been studied from different perspectives for decades, however due to the recognition of the multidisciplinary nature of violence disciplines such as human geography, planning and architecture have studied the phenomenon as well.

However, the greatest challenge for understanding violence is its conceptualisation. Traditionally and generally, violence has been defined as 'the intentional use of force or power with a predetermined end by which one or more persons produce physical, mental or sexual injury, injure the freedom of movement, or cause the death of another person or persons' (Concha-Eastman 2002, p. 44). Yet, violence also can be understood and categorised according to different factors, including the types or manifestations of violence, the level of their impact; or identifying the victims or the perpetrators of violent acts, among others (World Bank 2011; Shaw 2009).

Recognising these challenges in the study of violence, this article focuses on interpersonal violence manifestations and on urban violence, moving from a conceptual perspective to an analytical one, which 
will aid in untangling the interactions between urban space -and the processes generating it - and urban violence. This approach permits to look simultaneously at urban space as the process through which urban violence proliferates and different manifestations of violence (Pavoni and Tulumello 2018), as experienced and lived in the urban space by citizens.

The article firstly and briefly presents theoretical debates regarding violence theories, focusing on socio-environmental ones (section one), in order to introduce in the following section (two), an adapted version of the ecological framework for violence (WHO, 2016), which will be later used to analyse the case study presented. Section three introduces the context of Mexico regarding violence, followed by the urban space characteristics of the case study: a peripheral settlement called 5 de Febrero in Culiacan, Mexico. Section four discusses the implications of using the framework of urban violence, whilst section five provides conclusions of the article.

\section{Understanding violence in urban areas from behavioural to so- cio-environmental to urban violence theories}

Trying to make sense of the 'new' realities of violence and insecurity in Latin America (Briceño-León et al. 2008; Concha-Eastman 2002; Rotker and Goldman 2002), and as scholars and policy makers try to further understand crime and violence, two dominant approaches have emerged. The first focuses on the origins, nature and extent of violence, and the reasons for it spreading in cities of the developing world. The second approach centres on policy-oriented strategies and actions aiming to prevent and reduce the levels of crime and violence (Davis, 2012).

This article, on one hand, focuses on the types of violence which tend to occur in urban areas, that is, interpersonal manifestations of urban violence and their interaction with urban spaces, hence, manifestations such as domestic violence - that tend to occur in private areas- are not investigated. On the other hand, the article investigates the role of planning - or the production of urban space from an institutional perspective - both as a potential cause as well as a response to violence.

Since this article has a contextual focus -e.g. urban space and planning- a sociological point of view, is helpful in acknowledging the underlying critical factors associated with violence. With this approach, violence is viewed as a social process (Scheper-Hughes and Bourgois, 
2003) - similar to urban space which is socially constructed - which interacts with urban space, understood from a citizen's perspective. In this sense, a focus on urban space allows analysing the impacts of urbanisation and how the configuration of social -and planning- processes can act as determinant risk factor affecting urban space and in turn inciting certain types of violence (Davis 2014; Pedrazzini et al. 2014; Moser 2004).

\section{Social environmental theories}

A long tradition of theory in criminology research has looked into social environmental factors and geographic variations in crime and violence (Hagan, 2012). These theories are among the major theoretical approaches to violence and crime, for example, the relative deprivation theory (Kawachi et al. 1999; Walker and Pettigrew 1984) and the anomie or strain theory (Merton, 1938).

More recent studies have established that the emergence of violent behaviour is determined by a combination of macro and micro-level factors -also referred to as structural causes and trigger factors (Moser, 2004) - that have an impact on someone's decision to engage with violence. More precisely, the World Bank (2011, p. 19) established that "there is no one direct cause in personal development" that leads straight to violent behaviour; nonetheless, several characteristics of an individual's biology, personality, and environment impose certain stresses that have been acknowledged to increment risk factors that induce individuals to perpetrate or experience violence" (World Bank, 2011). These risk factors are analysed at different levels of impact, individual and societal, and from a public health approach, and have been synthesised in the 'ecological framework for violence' (WHO, 2016).

\section{The ecological framework for violence (background)}

The ecological model or framework allows an understanding of violence according to risk factors affecting different levels of analysis. This means that violence cannot be explained by a single variable; it is rather seen as a product of interacting factors at individual, relationship, community and societal levels (WHO, 2016).

Conceptually, it is a broad paradigm mainly drawing attention to the importance of multi-level and multi-dimensional approaches to social relations and phenomena (Kemp 2015). In the 1930s, the Chicago School, in 
proposing that qualitative methodologies as naturalistic observation would be best fitted for the study of urban and social phenomena, introduced the idea of exploring the complexities of social interactions through ecological models (Lutters and Ackerman, 1996).

'Ecological' refers to the study of the relations between an organism and its surroundings, in this case, social units of analysis, i.e. individuals, communities and their social and urban environments (Kemp 2015; Lutters and Ackerman, 1996). The ecological model "emerged from actively examining the parallels between natural and social systems" (Lutters and Ackerman 1996, p. 4). However, these were not developed into theories and a framework per se until the 1970s and 1980s (Lutters and Ackerman 1996).

Bronfenbrenner (1977) argued that, for comprehending human development, it was necessary to analyse the ecological system where growth happens. Bronfenbrenner (1977) identified five categories or levels: individual, micro-system, meso-system, exo-system and macrosystem. Here, the macro-system comprises the attitudes or ideologies of the culture; neighbours or family friends represent the exo-system; and the meso-system is the linkages or processes, in other words a system of microsystems. Lastly, a micro-system encompasses interpersonal relationships (Bronfenbrenner, 1977).

Recently, the World Health Organisation (2016) has applied the ecological framework to violence prevention from a public health approach. The levels employed by the World Health Organisation are individual, interpersonal, community and societal (WHO, 2016). Figure 1 syntheses examples of risk factors at different levels of analysis, showing a modified framework, with an added "urban" level, allowing for an exploration of violence in a way that pays more attention to urban and contextual factors (Garcia, 2018). This framework will be used later to analyse the findings of Colonia 5 de Febrero.

This article focuses on how violence transforms the physical landscape as well as how the physical environment -and planning processes- might entice the appearance of violence. Undeniably, the built environment has important links with urban violence that have been studied before, and this relationship is more complex than frequently assumed. It is now recognised, and will be illustrated later in this article, 
that inadequate basic infrastructure provision, lack of or deficient public spaces, narrow alleyways, and the absence of street lighting are factors that generate the conditions and opportunities for the certain types of violence and, consequently, urban insecurity (Schneider and Kitchen, 2007).

As shown by Gold (1970) more than four decades ago, while the causes of violence may be multi-dimensional, particular importance may be attributed to the influence of the physical environment over violent behaviour and violent crime.

Figure 1. Socio-environmental risk factors for the emergence of violence

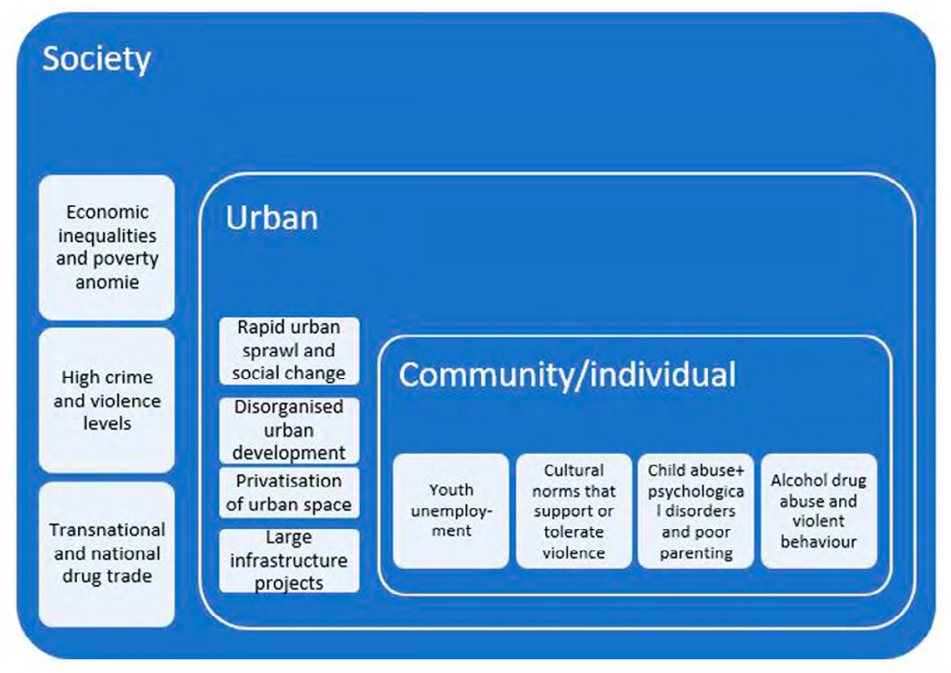

Source: adapted from WHO (2016)

As urban violence and its many manifestations become less spatially restricted, they stop being confined to specific areas of cities such as 'the urban margins' where they have historically mainly affected the urban poor (Auyero et al, 2015; McIlwaine and Moser, 2007). This has prompted a surge in research on the 'geographies' and 'spatiality of violence' (Springer and Le Billon, 2016), the 'territoriality of violence' (Valenzuela- Aguilera, 2013), and how violence 'sits' in places (Springer, 2011). Scholars have emphasised the territorial, social and economic repercussions that the "spatial distribution of violence and its concentration in certain urban spaces" have (Davis, 2012, p. 23). Following this line of research, the 
article will focus on examining residents' perceptions of violence and insecurity, in relation to the urban space.

\section{Violence manifestations}

With the ecological framework as a basis, a discussion about what urban violence entails is necessary. Contemporary manifestations of violence and insecurity have been recognised to be increasingly 'urban', in the context of Latin America (Glebbeek and Koonings, 2016). Pavoni and Tullumelo (2018, p. 2) argue "urban violence (and the fear thereof) can be said to emerge out of the intersections between structures, processes, narratives, practices and bodies that constitute the urban".

They continue appealing for a further theorization regarding the "urban" in urban violence as necessary. Arriving to a point where we ought to consider "understanding the urban both as the background out of which violence becomes manifest as an event, as well as the process constitutive to violence itself [...] assuming the urban both as the affective atmosphere of violence as well as a specific process responsible for producing the conditions in which given forms of violence proliferate" Pavoni and Tulumelo (2018, p. 3).

Urban violence can be understood as a phenomenon manifested through pervasive territorial control mechanisms which affect large sections of the population, directly or indirectly (Glebbeek and Koonings, 2016). Additional to this set of characteristics, a distinction of 'urban' violence is the fact that it encompasses a myriad of manifestations of violence that are often linked (Moser and Horn, 2011; Moser, 2004). Thus urban violence is not one, but many types of violence. Rather than having a fixed definition, it manifests itself through a continuum of 'violences' (Auyero and de Lara, 2012). Another recognised category is structural violence. It occurs when violence exists without the victim-perpetrator direct relation, e.g. violence built into uneven economic resources and power structures (Pansters, 2012; Galtung, 1969), such as urban planning. As the range of types of urban violence and crime are complex and context-specific, Moser (2004) distinguishes between structural causes and trigger risk factors.

Structural causes are understood as unequal power relations, while trigger risk factors comprehend situational circumstances that can aggravate the possibility of violence occurring (Moser, 2004), corresponding to situational circumstances e.g. conditions of the built 
environment, violence impacts on urban space; and structural causes, in particular planning processes which create conditions allowing certain types of violence to occur.

Thus the differentiation between structural and risk factors underpinning violence show that no single cause provokes, determines or explains violence (Moser, 2004). This point is precisely what the ecological model tries to highlight through its multidimensional approach.

Based on the several theories that undertake different levels of analysis to explain the appearance of violence, the ecological framework provides a multi-faceted way to move forward. Thus, the next section explores how spatial inequalities might be generating socio-spatial patterns of urban development, which in turn might attract or influence certain violence manifestations.

\section{Socio-spatial inequalities and the 'violence of urbanisation'}

Perceptions of violence and insecurity have been recognised to play a role in the spatial segregation of cities. Authors like Caldeira (1996) noted that the rising construction of gated communities was linked to enhanced urban insecurity in Brazil. Urban violence and insecurity may thus be seen both as a cause and a consequence of urban transformations.

This has taken many forms from Argentina to Chile to Central America. In Chile, Ward (2009, p. 131) suggests that this occurs in a more subtle way, even by "closing off a street behind chained gates" and "keep[ing] out undesirables". In Central America, (Rodgers, 2004) suggested that 'fortified enclaves' caused by fear of crime in Managua, Nicaragua contribute to changing patterns of urban spatial organisation in the city. This resulted in what he referred to as the 'disembedding' of a 'layer' of the city where elites are segregating themselves through the construction of high-speed roads and roundabouts.

Moreover, Ward (2009) suggests that segregation should analysed at or 'unpackaged' at various scales or levels, specifically for the case of Mexico. Ward (2009, p. 130) purports that, while on a macro-scale there is apparently no "intensification in segregation levels", at a micro-level, "lines are being drawn in the sand between neighborhoods". This segregation is reflected in several traits shared by Latin American cities: "closing off streets, creating no-go access zones, and by [citizens] barricading 
themselves behind high fences and armed guards" (Ward 2009, p. 130), ultimately resulting in the privatisation of space (Sabatini, 2006).

Changes in the configuration of space can also stimulate the appearance of violence (Pedrazzini et al. 2014, p. 394) and aim to "shift the blame [of violence occurrence] to the urbanisation process itself". Disorganised urban planning characterises urbanisation processes in cities of the global south, which reinforce socio-spatial fragmentation, and converting the physical environment becomes a source of "material and symbolic violence" (Pedrazzini et al. 2014, p. 394) in urban space. Urban violence is therefore seen as an intrinsic part of an urbanisation process that generates certain forms of social and spatial fragmentation (Pedrazzini et al., 2014).

Under the premise that urban space is socially produced and that urban space structures social conduct (Lefebvre, 1991), implications that echo behavioural explanations of violence arise (Colombijn, 2016). As people constitute urban space, urban space shapes behaviour, to a certain degree (Colombijn, 2016). One thing to note about this interaction - between urban space and urban violence - is that "the strength and prevailing direction of the mutual impact between space and behaviour depends on the severity of violence, real or imagined" (Colombijn, 2016, p. 16). This stresses the importance of perceptions of violence and insecurity. So, what is critical about the relationship between urban space and urban violence is that just as spatial inequalities generate violence, certain types of violence reinforce urban spatial inequalities and fragmentation (Hita and Sanchez, 2013).

As urban violence and its many manifestations become less spatially restricted, they stop being confined to specific areas of cities such as 'the urban margins' where they have historically mainly affected the urban poor (Auyero et al, 2015; McIlwaine and Moser, 2007). This has prompted a surge in research on the 'geographies' and 'spatiality of violence' (Springer and Le Billon, 2016), the 'territoriality of violence' (Valenzuela- Aguilera, 2013), and how violence 'sits' in places (Springer, 2011). Scholars have emphasised the territorial, social and economic repercussions that the "spatial distribution of violence and its concentration in certain urban spaces" have (Davis, 2012, p. 23). 
Natalia Garcia-Cervantes

Violence and insecurity in urban space: an analytical approach based on the ecological framework for

violence.

\section{Context in Mexico: the case of Culiacan (Mexican violence trends and Culiacan background)}

\section{Research context and methodology}

The article presents part of a comparative study of two Mexican cities, Culiacan and Aguascalientes, and two neighborhoods within each city, using a mixed method approach. Geo-referenced surveys were complemented with qualitative methods, namely semi-structured interviews, participant observation, transect walks, auto-photography and risk mapping assessments.

Quantitative data-both primary, which was collected by the researcher, and secondary, collected from existing surveys and official statistics - were used to examine the impacts of violence in urban space and how these vary geographically within the case studies.

Given the complexity and richness of the data recovered in Culiacan, Sinaloa, particularly in the peripheral settlement, and considering that the characteristics of this type of settlement might resonate with other locations, the data gathered from colonia 5 de Febrero is presented in this article.

A total of 137 surveys were conducted for the research -31 in 5 de Febrero; followed by 22 semi-structured interviews, additional to 27 interviews with planning officials conducted at city level, where institutions were selected based on their involvement in urban planning matters. Participatory methods, auto-photography and risk mapping were also conducted with 6 and 4 participants in this community, respectively. Further detail on methodological matters can be found in Garcia (2019).

- Urban violence and insecurity in Sinaloa

The state of Sinaloa is internationally known for being the birthplace of one of the most powerful drug cartels in Mexico and in the world (Hernandez 2013; Grillo 2013). The history of violence in Sinaloa and particularly in the state capital, Culiacan, can be traced to the origins of the Sinaloa cartel; mainly expressed in terms of homicide rates. From its beginnings, the cartel set the precedent for what now is identified and accepted as 'narco-cultura'?

2 The term 'narco-cultura' refers to the cultural impact of drug trafficking [narco-trafico]. Rather than an artistic or 'cultural' tendency, it is a 'way of life' related to a structure of values marked by violence and expressions of material aspiration. It is particularly associated with young males involved in criminal organisations. Narco-cultura behaviour is characterised by a tendency to violence, exacerbating [based on an exaggerated notion of] traditional values such as honour, courage and family. For example, extreme 
Sinaloa has witnessed some of the most alarming rises in violence in the country since 2006; based on official statistics of homicide rates, Sinaloa is one of the most violent states (SEGOB and SESNSP, 2010).

However, the region has relatively low levels of the other categories of crime as defined by the $\operatorname{SESNSP}^{3}$ (Table 1). Even though official records of non-fatal violence are low, these manifestations of violence impact on citizens' perceptions of violence and insecurity, and authorities tend to pay less attention to recording figures accurately.

Furthermore, this study found that official data does not explain what is happening at community and neighbourhood levels; it provides generalisations of violence and crime at city and state levels that fail to capture how 'low impact' violence affects citizens on a daily basis. In this sense, static classifications and quantitative measurements of violence do not grasp the impacts of violence, insecurity and crime on people's lives.

Sinaloa and Culiacan allow putting matters in perspective. In 2015 Sinaloa reported the highest regional homicide rate in Mexico, with 22.8 victims per 100,000 inhabitants, exceeding the national rate which was 15.25 victims in the same period (Observatorio Nacional Ciudadano, 2015). The homicide rate in Culiacan city was nine per cent per 100,000 inhabitants higher than in Sinaloa state. According to Observatorio Nacional Ciudadano (2015) Culiacan presents levels greater than those registered at state level, with 41.2 per cent more homicides, 32.48 per cent more kidnappings and 62.41 per cent more violent robberies. Undeniably, homicide rates have a great impact on a citizen's perception of violence, but at community and neighbourhood level, there are other manifestations of violence (for example, domestic and economic violence) which also affect perceptions and undermine the wellbeing of residents.

loyalty is rewarded and betrayal or attempts to leave the organisation are punished by physical violence and death. Another important characteristic is that of 'power yearning' in a compulsive quest for social status. It is said that those involved in drug trafficking seek to 'live fast and die young', lacking a long-term horizon since they can be murdered at any time (Cabañas, 2014).

3 These are crimes against: Life and physical integrity (homicide, assault); Personal liberty (kidnapping, trafficking of children); Freedom of and sexual security (sexual abuse, rape); Property (burglary, car theft, mugging); Family (domestic violence); Society (corruption of minors, drug dealing); and Others (trespassing, extortions) (SEGOB and SESNSP, 2013) 
Table 1. Comparison of Sinaloa (state) and National crimes

\begin{tabular}{|c|c|c|c|c|c|c|c|c|c|}
\hline & \multicolumn{3}{|c|}{ Crimes against life4 } & \multicolumn{3}{|c|}{ Personal liberty } & \multicolumn{3}{|c|}{ Property } \\
\hline$\underset{\nu}{\vec{\varpi}}$ & 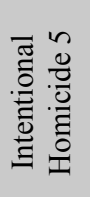 & 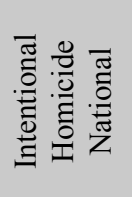 & 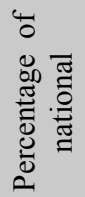 & 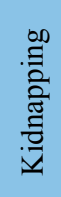 & 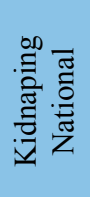 & 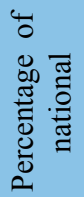 & 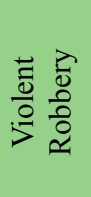 & 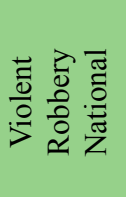 & 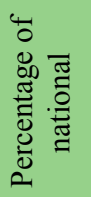 \\
\hline 2005 & 1258 & 25771 & 4.88 & 6 & 278 & 2.15 & 2151 & 146176 & 1.47 \\
\hline 2006 & 1407 & 27552 & 5.09 & 9 & 733 & 1.22 & 2002 & 146508 & 1.36 \\
\hline 2007 & 1455 & 25133 & 5.78 & 15 & 438 & 3.42 & 2208 & 159765 & 1.38 \\
\hline 2008 & 1844 & 27759 & 6.64 & 12 & 907 & 1.32 & 2909 & 175333 & 1.65 \\
\hline 2009 & 1986 & 31546 & 6.29 & 18 & 1162 & 1.54 & 3873 & 197240 & 1.96 \\
\hline 2010 & 2,863 & 35713 & 7.94 & 17 & 1222 & 1.39 & 8174 & 229076 & 3.56 \\
\hline 2011 & 2587 & 37952 & 6.81 & 33 & 1432 & 2.30 & 8831 & 243831 & 3.62 \\
\hline 2012 & 2066 & 38227 & 5.40 & 32 & 1418 & 2.25 & 7183 & 222408 & 3.22 \\
\hline 2013 & 1826 & 34903 & 5.23 & 34 & 1698 & 2.00 & 5758 & 215718 & 2.69 \\
\hline
\end{tabular}

Source: Author, based on information by SEGOB and SESNSP (2005-2013).

Although it is understood that urban violence and insecurity have spread through the country variably, what is less known is how urban violence and insecurity within specific cities affect diverse neighbourhoods. The next section analyses the state of the urban space and violence processes at the peripheries in the city of Culiacan.

\section{A peripheral settlement in Culiacan: 5 de Febrero}

Colonia 5 de Febrero is located in the western outskirts of Culiacan (figure 2), and was founded between 1985 and 1987 by a squatter movement. After a few years land tenure was partially legalised and basic services were gradually provided following constant negotiations with the municipality. The location of the colonia and its foundation has characterised its socioeconomic development.

In 2010 it had 3,978 inhabitants, of whom 50.1 per cent were female and 49.9 per cent male (IMPLAN Culiacan, 2010). The colonia consists of some 1,000 plots of land, and around the same number of houses, with an approximate density of three to five people per house. Surveys conducted

4 Based on the seven categories established by SESNSP discussed previously

5 Total reported by state, this does not take into account unreported crime, known as 'black data'. 
in the area indicate that the largest age group was 48 or above ${ }^{6}$. According to the survey conducted in the area, 54.8 per cent of the households in 5 de Febrero have monthly incomes below $\$ 4,000$ pesos (about $£ 200$ at the time of fieldwork ${ }^{7}$ ). The majority of the respondents' occupations were housewives, services, and commerce (mostly informal). Most of the inhabitants work outside the colonia.

Figure 2. Location of colonia 5 de Febrero in Culiacan, Sinaloa

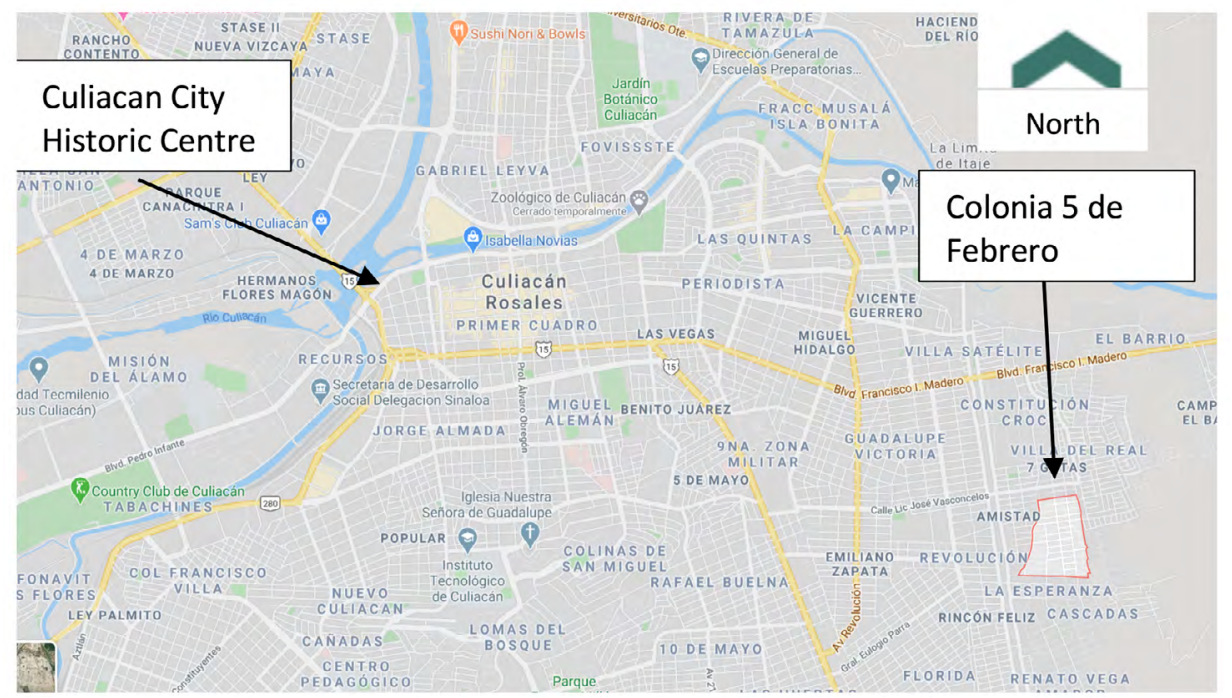

Source: Google Maps, 2015.

Regarding the conditions of the built environment in the colonia, the settlement is physically separated from other neighbourhoods - and the rest of the city of Culiacan - by a stream ('Arroyo 2'), which also forms the limits of 5 de Febrero (figure 3).

To access the colonia, there are two bridges for vehicles and pedestrians (Photo 1), making the neighbourhood is physically bounded by the stream- problematic area as is used as an illegal waste dump leading to a high water contamination as identified by inhabitants.

\footnotetext{
6 The sample of surveys conducted for this study did not attempt to be statistically representative; rather, it aims to offer a characterisation of the respondents' age, gender, income and occupation.

7 The exchange rate during fieldwork was of $£ 1$ equal to about $\$ 20$ Mexican pesos
} 
Photo 1. View of the stream and the bridge to access the colonia

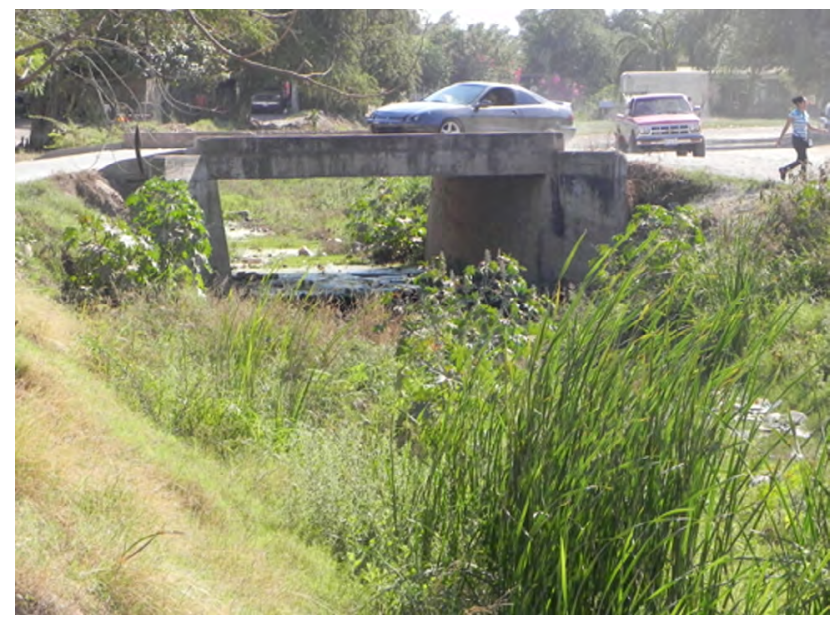

Source: author, based on Google Maps 2015

The case of 5 de Febrero illustrates the relative control the city had over the irregular occupation of land, and how inhabitants expanded the limits of the city, legally recognising these colonias and providing for basic services after a few years of being founded. Also, regular housing developments or "fraccionamientos" push the physical limits of the city and the municipality allows and even incentivises developers to do so with many liberties.

Adding to this, fraccionamientos are developed with little regard to their surrounding areas; for example, the access to 5 de Febrero was curtailed and the neighbourhood was physically separated from a neighbouring development, with a bordering wall constructed in 2012 .

Many residents in 5 de Febrero are preoccupied by the existence of a newly squatted area on the outskirts of the neighbourhood which began to be occupied in 2012. The land is at the very limits to the city, where services and infrastructure are still precarious and inhabitants do not have formal access to basic services (Photo 2).

Additionally, it is presumed by 5 de Febrero inhabitants that some houses in the squatter area are used for drug trafficking, including people watching over the area, mostly young men in their twenties. They illegally obtain electric power from the utility poles and access water through stored 
Violencia e inseguridad en el espacio urbano: un enfoque analítico basado en el marco ecológico para la violencia.

Figure 3. Colonia limits, main streets and roads in 5 de Febrero

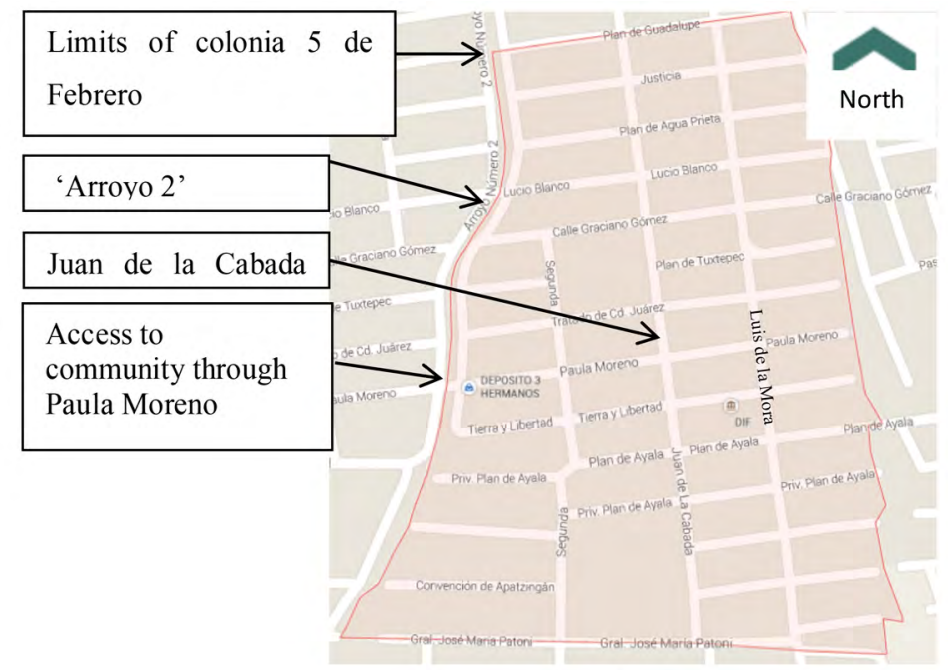

Source: author, based on Google Maps, 2015.

water tanks. This situation resulted in residents of the colonia 5 de Febrero registering their dissatisfaction with a manifestation in state Congress in 2012. Members of the community argue that:

It's some of the people from the 'invasion' that come and rob at our houses by night, or they assault young girls when they come back from school. They are the ones making us feel insecure (interview Diana, 2015).

Photo 2 . View of the squatter settlement

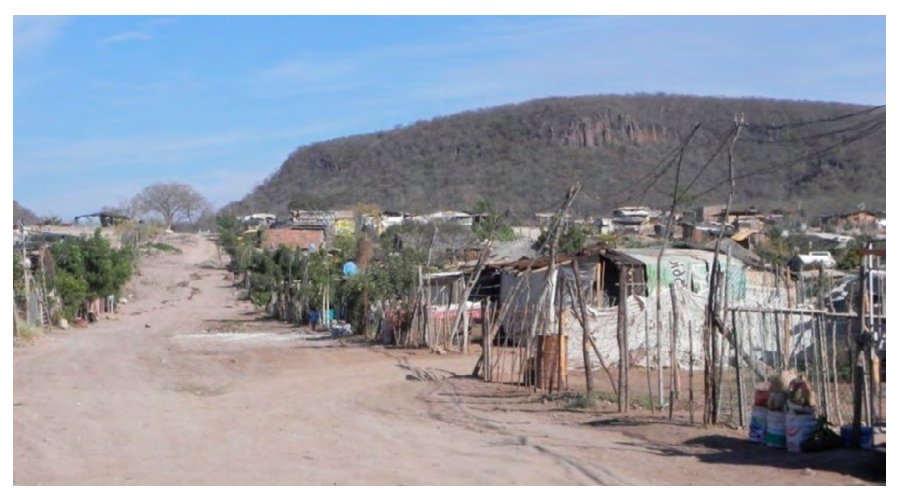

Source: author, 2015 
The invasion is of particular interest as it illustrates critical issues, such as the deliberate appropriation of an unused, unserved and relatively isolated area at the edge of a peripheral neighbourhood, and how it might have enabled criminal activities to take place, affecting the wider area, and how these areas interact with and affect 5 de Febrero residents' perceptions of violence and insecurity. These areas among others in the community play a key role in relation to perceptions of violence and insecurity in the colonia.

- Violence, insecurity and urban space: perceptions in a peripheral colonia

5 de Febrero is known in Culiacan for being a violent and dangerous place (interview Culiacan Participa staff, 2015). Official data regarding actual criminal violence in the sector was unavailable since "it is classified and cannot be open for public consultation" (Secretaría de Seguridad Pública y Tránsito Municipal, 2015).

From the accounts of respondents, it can be understood that urban violence-in its multiple manifestations - and insecurity have been accepted and normalised by inhabitants as an intrinsic part of their everyday lives. Respondents are aware that violence and insecurity - both as a fact and a phantom (Pansters and Castillo-Berthier, 2007), direct or indirect - exist in their surroundings, and they are forced to learn to live with violence. This endurance to violence from long-term association has implications for the ways in which inhabitants construct their mental conceptions of urban space and thus adapt their routines to places they consider 'safe' (Figure 4).

The study found that most of the population maintained they felt secure and that there were no violence issues in the community. Yet, although respondents said they felt safe, they often inadvertently mentioned several types of violence and recalled having experienced or being aware of violence-related incidents occurring within the community. One of the first community members interviewed, Juan mentioned:

8 This was the response to two official requests made to the Secretaria de Seguridad Publica y Transito Municipal (personal records) 
I feel[...] very secure, I know that there is danger but I feel ok ... I went to talk to them [alleged delinquents] because they stole a water meter from my house [...]. So I confronted him [the thief]... ... just to let them see that they are doing wrong, they're robbing and using drugs in public spaces... I have already been shot at for confronting them, without being rude ... but I feel safe, like I said, I love this place and here I'm going to die (interview Juan, 2015).

Here Juan acknowledges robbery, drug use in public areas and being shot at as issues within the community, but for him these are not violent incidents. Other respondents also said they feel safe in the area, while identifying types of violence such as attempted rape and assassinations. In this way, there are hints at normalisation of violence in the area and how violence as a form of 'culture' is internalised (Galtung, 1990). For example:

I feel very, very safe. Nothing has ever happened to me, or my family ... Although, I will contradict myself, a few months ago, I heard that a young guy was 'levantado"' from here [one block from her house], and he was later found assassinated. But he was 'on the wrong path' [involved in criminal activities]... And a few weeks ago, there was an attempt of rape by the stream, it gets really dark at night and a couple of young girls were coming back home; they were really scared but they were safe... (interview Diana, 2015).

With this last expression, Diana was referring to a tale where, if a frog is placed on a pot of water and brought to the boil, it will remain there, whereas if the frog is placed straight into boiling water it will jump out immediately. What she meant is that, she is used to the rising levels of violence in the colonia, since she has always lived there. Diana perceives her colonia as a safe place because she has never been a victim of a crime in this area. Other respondents mentioned these types of comment as well.

9 'Levantado' is a term used in Mexico, especially in States with evident presence of organised crime. It refers to a person being kidnapped or abducted generally with the aim of assassinating the victim. Most 'levantados' remain missing or their bodies are dumped at the outskirts of the city where this happens. 
Figure 4. Security perception, 5 de Febrero

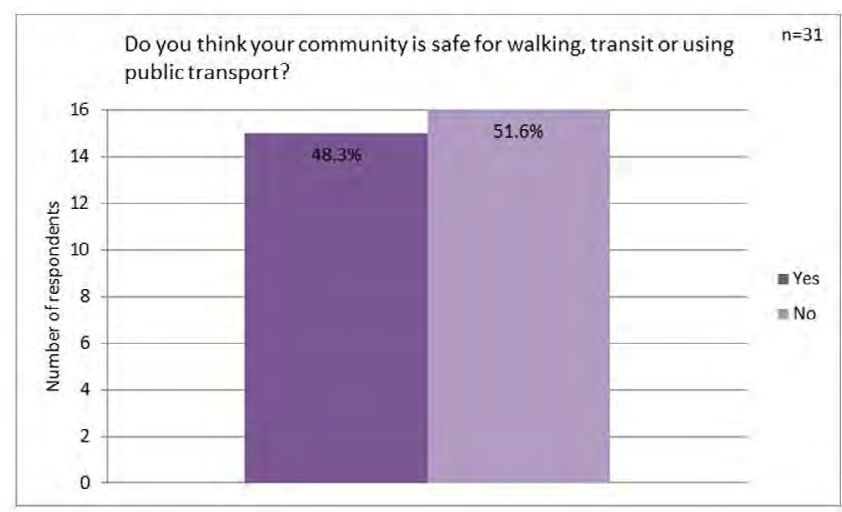

Source: author, based on surveys from fieldwork 2015.

- Violence manifestations and spaces of violence and insecurity

On experiences of crime, 74.2 per cent of participants reported having been a victim of a crime in the area, while 25.8 per cent said they had not (Figure 5). In other words, even when most of the population has been a victim of a crime, half of the respondents still feel safe in the area. Participants' perceptions ranged from "it is very calm and pleasant; nothing happens here anymore" to "you cannot walk alone at night, they'll rob you or you will be "levantado"”.

Figure 5. Crime victimisation in 5 de Febrero

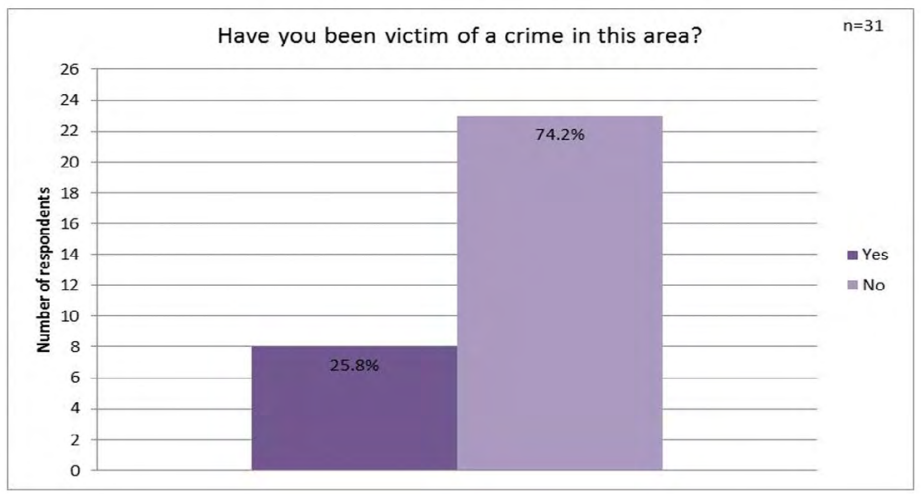

Source: author, based on surveys from fieldwork 2015. 
A prominent issue in the area is crime underreporting. As is the case in many poor communities, distrust towards the police or authorities is generalised (Howard et al., 2007; McIlwaine and Moser, 2007). Police patrol presence in the area is rare; they do not patrol at night, according to several residents, some respondents suggested that police responses might actually exacerbate their fears and perceptions of insecurity. The director of a civil society organisation working in the area discussed one of the reasons why people do not report crimes:

People used to report crimes, or call the police if they saw someone robbing or using drugs in public spaces. Then police used to come, arrest the responsible person and after half an hour or less, they would let them go in another area of the colonia, telling them who had pointed a finger towards them; allowing them to retaliate. This is why people do not report crimes or trust the police. Because, who would, really? (interview Culiacan Participa, 2015).

Participants reported having been victims of robbery, assault or burglary. Respondents said they had been direct victims of crime or knew someone who had. This was the case of Caro, a community leader whose nephew had been 'levantado'. Through her experience she exposed the complexity of the violence situation in the colonia. At the start of the interview, her response regarding security was blunt and short. When asked how safe she felt in the colonia, she answered:

I feel very safe here, this is a safe colonia, everybody knows who I am, and they come to me to ask me for things, candy for kids, medicine for the sick... it is all good, it's a good colonia (interview Caro, 2015).

As the interview moved forward, after an hour or so, the question was rephrased, and her answer changed drastically:

You have to be from here [ 5 de Febrero], to be able to walk around here. if you're a stranger ... come at night and see if you get out of here alive... Who are they? [the perpetrators] We do not know. I do not go out at night but I know that there is one and there is another one and they were beaten up and 'levantados'. The mother of one of them [the victims] came and told me "Ay, Caro, my son was 'levantado"'... and then another one, a few months later said "Caro, they killed my son." . these are kids who are at the canchas [football court next to CESAVVI], at two, three, four in the 
morning, They are doing bad things... that is why they get 'levantados' [...]... When they killed my nephew, the only thing I told them was, "You know what? If you already killed him, just give me his body so I can bury him"... The next day the body appeared. [..](interview Caro, 2015).

After her account, Caro insisted she feels 'very secure' in the colonia. This is one example of the criminal violence to which inhabitants are exposed; in their experience, this kind of violence has been 'normalised' when it occurs to 'certain type of persons' (Howard et al. 2007; Moser and McIlwaine 2006).

The violence in the colonia is usually associated with specific places, with the exception of domestic violence which tends to occur in private spaces (Meth and Malaza, 2010). Some places in the colonia are associated with insecurity because homicides have taken place there. Processes of violence appear thus to be embedded into contextual and institutional settings (Moser and Horn, 2011). These might be entrenched via institutional processes, such as planning, exemplified here by three areas: las canchas, the stream, and 'las invasiones'. These three areas can be then related to three issues: failed socio-spatial intervention, deficient infrastructure and unplanned development.

Las canchas area is an example of an arguably failed attempt to improve public space; this area was the focus of a federal-led intervention to improve public spaces ${ }^{10}$, contrary to the programme expectations, was consistently mentioned as insecure by respondents. Inhabitants stopped using this area due to the presence of drug addicts and vandalism, in addition to feeling fear of being robbed.

According to respondents, the lack of community involvement and the inadequateness of official interventions tends to exacerbate feelings of insecurity, creating a potential location for violence and crime. The provision or improvement of public and recreational areas is often included within violence reduction strategies that consider the built environment (Mexico Evalua, 2015). These spaces are meant to work as a focal point and to bring together the community to host a variety of activities, since some infrastructure was provided. Yet, these improvement programmes

10 'Programa Rescate de Espacios Publicos, PREP' in 2012 by SEDESOL 
have various limitations exemplified by the case of 5 de Febrero, ultimately exacerbating feelings of insecurity.

Deficiencies in terms of infrastructure and public services are also seen as a factor that negatively affects perceptions of security. Another area consistently identified as insecure is the stream (or Arroyo 2). In the case of the stream, perceptions are influenced by lack of infrastructure pavement and lighting - and the fact that bodies have been found there, allegedly related to domestic violence (Noroeste Redaccion, 2010).

It can be argued that there are some places in the colonia where violence and insecurity are directly linked to violent incidents happening. Other places associated with insecurity are more straightforwardly related to poor environmental conditions (e.g. las invasiones and the stream).

In some other instances, violence and insecurity are linked to places where interventions to reduce insecurity have failed. It is thus challenging to draw a direct link between the built environment and insecurity, since in some cases, regardless of the fairly good conditions an area might have inhabitants still feel insecure while transiting through or using those spaces.

This echoes the importance of perceptions in the configuration of urban space and the role of planning, as by action or omission planning creates certain conditions that enhance insecurity. These findings suggest that further understanding and incorporation of "the urban" is needed to achieve better understandings of violence and insecurity patterns, attractors, actors and potential causes.

In 5 de Febrero, the four levels of risk factor in the ecological framework - individual, community, urban and social levels - interact in different ways to account for violence and insecurity. Additionally, planning processes seemed to affect the relation between risk factors.

\section{Discussion: (Re)constructing urban space through violence and insecurity using the ecological framework}

The empirical evidence presented here permits analysing the interrelated nature of violence and the risk factors leading to its proliferation, paying especial attention to the role of the "urban" in urban violence (Pavoni and Tulumello, 2018).

This is done at individual and community, urban and societal levels, as suggested by the adapted ecological framework for violence discussed 
before. The framework is presented again below, with alterations that permit considering these factors more clearly. (figure 6)

Figure 6. Adapted ecological framework for violence

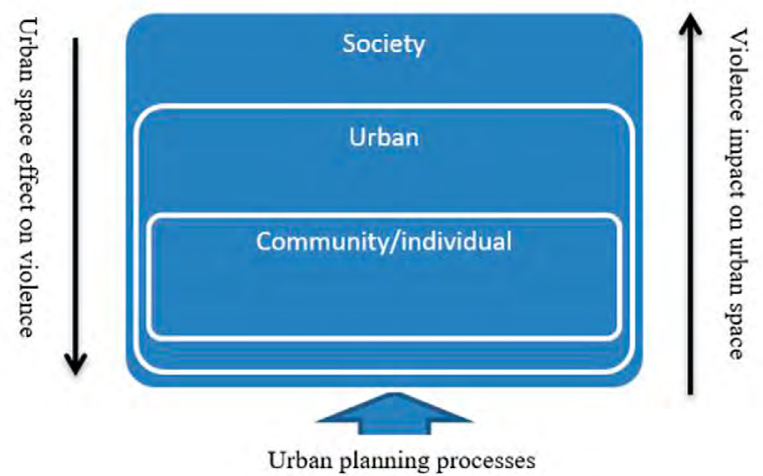

Source: modified from (WHO 2016)

As proposed previously, societal, urban, community and individual level factors interact to stimulate violence, in line with the ecological framework for violence.

The framework shows urban violence has an effect on urban space for example, through the production of fortified enclaves, privatisation of space, etc - institutionalising spatial segregation through active or passive planning and in this way enticing manifestations of violence. Urban space has equally an effect on violence; it is here where planning might mediate the conditions of urban space, in order to enhance or minimise perceptions of insecurity and locations where opportunistic crime is likely to occur. In a way, both processes are mediated to some extent by planning processes.

1) Individual and community levels

The individual level risk factors relate to child and domestic violence and drug abuse, fuelled by the presence of social and economic violence. For example, respondents point out the 'youth' as the usual culprit for crime and violence in 5 de Febrero; young people seem socially and economically driven to engage with violence -this interpretation is based on residents' perceptions.

Violence represents a means to obtaining material goods, which in turn, are thought to signify social status. In this sense, belonging to 'those 
who can' or criminals involved in narco-violence, also empowers them, further fuelling violence cycles (Jütersonke et al., 2009; Winton, 2005).

2) Urban level

Establishing causality between planning, insecurity -or fear of crime- and urban violence is challenging. The evidence has shown that this relation works in different ways. On the one hand, planning processes enhance forms of spatial segregation affecting urban space in a way that might incite incidents of violence.

On the other hand, increased violence and insecurity prove that citizens limit their interactions, which also affects urban space. For Tulumello $(2015$, p. 268) the impacts of insecurity and fear of crime are spatial and discursive practices, and often a cause of "less civic urban lives". This implies that citizen interactions are limited, leading to a physical and social fragmentation of cities. The pervasiveness of violence, accompanied by abundant perceptions of insecurity justifies in many cases this reshaping of the built environment.

The lack of infrastructure, failed physical space interventions and fragmentation of urban spaces support the argument of the failure of to recognise the diverse and complex nature of urban violence of the planning processes in Mexico. Understanding violence from a perspective that goes beyond physical space is essential to arriving at "a more integrative understanding [of urban violence and insecurity], acknowledging that even the most seemingly place-bound expressions of violence are mediated through and integrated within the wider assemblage of space" (Springer and Le Billon 2016, p. 2).

\section{3) Societal level}

The societal context and the risk factors at this level influence whether violence is accepted or discouraged. Calderon (2018, p. 101) argues that it is necessary"to understand the social processes that define the meanings that every society assigns to violence. These include stark socio-economic inequalities, particularly present in Mexico (Esquivel 2011); weak rule of law; the availability of weapons; and overall social norms that "endorse violence as an acceptable method to resolve conflicts" (WHO, 2016). In the context of Mexico, the appearance of violence is highly influenced by social as well as political and economic factors. Azaola (2012) argues that violence in Mexico has a traditional societal facet. 
Added to this, the deep-rooted existence of drug trafficking in Mexico, and particularly in Culiacan, has generated particular dynamics that go beyond the scope of this article but must be noted, such as large numbers of unemployed young males involved in organised crime, an increasing number of orphans due to parents being murdered by narco-criminals, and a 'culture of admiration' for drug traffickers and criminals (Valdez Cárdenas, 2017, 2015, 2007). In this sense, in the case of Mexico, and as put by Scheper-Hughes and Bourgois (2003, p. 1), the social dimensions are to be considered closely since these are what "give violence its power and meaning".

Exacerbating the issue, a theme illustrated in 5 de Febrero was distrust in the authorities. This speaks to what Azaola (2012) calls the weakness and disintegration of the police and justice institutions, which have contributed to a flawed rule of law (Azaola 2012). There is apparently little interest by the state in prosecuting and punishing crime and violence in peripheral neighbourhoods. This irremediably generates distrust in citizens towards institutions and processes, which should punish crimes.

\section{Conclusions}

The article looked into the different types of violence present through the community and presented an analysis of the physical conditions of where violence occurs. The need for a multi-faceted understanding of violence and insecurity, which is, in Tulumello's (2015, p. 258) words, a "complex and multi-layered world, comprising several dimensions, such as the psychological, sociological, cultural, and politico-economic" was emphasised.

The use of the adapted ecological framework for violence allowed conducting this analysis, detangling the different processes occurring at different levels in the appearance of violence. There are limitations to the framework presented here.

The study focuses on interpersonal violence occurring in public areas, not so much in other types of violence, such as domestic. Also, the framework could go into "higher" levels of analysis, such as international processes -i.e., globalisation or neoliberalism. However, the broadness and flexibility of the framework allow conducting analysis of violence 
manifestations in a variety of contexts and looking at different social processes -not just planning-, in order to provide clearness and precision.

The physical aspects of the community reflect and shape how life is lived within it, thus adding an urban dimension to the ecological framework permits recognising and taking this into account in the study of violence. It might enable, in Pavoni and Tulumello's (2018, p. 8) words to "[move] beyond the phenomenological event of urban violence, [to] now turn our attention to what is simultaneously the space (the urban) and the process (urbanisation) out of which it emerges as such.

In a way, 5 de Febrero reflects the living conditions at the city peripheries which might resound with a range of contexts throughout the world. The use of the framework here offers a more structured way of looking into violence, taking into account "the relational character of space and place, wherein any place-based phenomena, including violence, is comprised from and informed by the wider narratives of space" (Massey, 2005 in Springer 2009, p. 316). It has been suggested before that "any 'local' expression of violence is always and invariably connected to broader imperatives" (Springer 2015, p. 316). Thus, the use of the adapted ecological framework would allow considering the "wider structural conditions that potentially contribute to any act of violence" (Springer 2015, p. 316).

\section{References}

Arias, E, Goldstein, D, (2010). Violent democracies in Latin America. Duke University Press, Durham [NC].

Auyero, J., Bourgois, P., Scheper-Hughes, N. (Eds.), 2015. Violence at the Urban Margins, Global and Comparative Ethnography. Oxford University Press, Oxford, New York.

Auyero, J., de Lara, A.B., 2012. In harm's way at the urban margins. Ethnography 13(4), 531-557. Doi: 10.1177/1466138111435746

Azaola, E, (2012). La violencia de hoy, las violencias de siempre. REDALYC, Desacatos, Revista de Antropologia Social, pp. 13-32.

Bayón, M. C., Saraví, G, (2013). The Cultural Dimensions of Urban Fragmentation Segregation, Sociability, and Inequality in Mexico City. Latin American Perspectives 40, pp. 35-52. https://doi. org/10.1177/0094582X12468865 
Briceño-León, R, Villaveces, A, Concha-Eastman, A, (2008). Understanding the uneven distribution of the incidence of homicide in Latin America. International journal of epidemiology 37, pp. 751-757. https://doi.org/10.1093/ije/dyn153

Bronfenbrenner, U. (1977). Toward an experimental ecology of human development. American Psychologist 32, pp. 513-531. https://doi. org/10.1037/0003-066X.32.7.513

Buvinic, M, Morrison, A, (1999). Violence as an Obstacle to Development (Technical Notes). Inter-American Development Bank.

Buvinic, M., Morrison, A., and Shifter, M. (1999). Violence in Latin America and the Caribbean: A Framework for Action. Inter-American Development Bank.

Cabañas, M. (2014). Imagined Narcoscapes: Narcoculture and the Politics of Representation. Latin American Perspectives 41, pp. 3-17. https://doi.org/10.1177/0094582X13518760

Caldeira, T. (1996). Fortcified Enclaves: The New Urban Segregation. Public Culture 8, 303-328. https://doi.org/10.1215/08992363-8-2-303

Calderon, R. (2018). "Violence and social exclusion in urban contexts in Central America" in 'Social Theories of Urban Violence in the Global South Towards Safe and Inclusive Cities', Edited by Jennifer Erin Salahub, Markus Gottsbacher and John de Boer, Routledge, Oxon, pp. 99-121.

Colombijn, F. (2016). The Production of Urban Space by Violence and its Aftermath in Jakarta and Kota Ambon, Indonesia. Ethnos 0, pp. 1-22. https://doi.org/10.1080/00141844.2016.1138983

Concha-Eastman, A. (2002). Urban violence in Latin America and the Caribbean. Dimensions, Explanations, Actions, in: Rotker, S. (Ed.), Citizens of Fear. Rutgers University Press, New Jersey and London, p. 265.

Davis, D., 2014. Modernist Planning and the Foundations of Urban Violence in Latin America. Built Environment 40(3), 376-393 (18).

Davis, D., 2012. Urban Resilience in Situations of Chronic Violence. United States Agency for International Development (USAID), Massachusetts Institute of Technology (MIT) USA. 
DIF Culiacan, (2013). Home Page [WWW Document]. http://dif.culiacan. gob.mx/. http://dif.culiacan.gob.mx/

Esquivel, G. (2011). The Dynamics of Income Inequality in Mexico since NAFTA. Economía 12, pp. 155-179. https://doi.org/10.1353/ eco.2011.0009

Ferguson, K. Mindel, C. (2007). Modeling Fear of Crime in Dallas Neighborhoods: A Test of Social Capital Theory. Crime and Delinquency 53, pp. 322-349. https://doi.org/10.1177/0011128705285039

Garcia, N. (2019). Using Participatory Visual Methods in the Study of Violence Perceptions and Urban Space in Mexico. International Journal of Conflict and Violence, 13, pp. 1-15.doi: 10.4119/ijcv-3163

Garcia, N. 2018. The everyday effects of urban planning: exploring perceptions of violence, insecurity and urban space in two mexican cities. PhD Thesis, Global Development Institute, University of Manchester

Galtung, J, (1990). Cultural Violence. Journal of Peace Research 27, pp. 291-305. https://doi.org/10.1177/0022343390027003005

Galtung, J, (1969). Violence, Peace, and Peace Research. Journal of Peace Research 6, pp. 167-191.

Glebbeek, ML, Koonings, K, (2016). Between Morro and Asfalto. Violence, insecurity and socio-spatial segregation in Latin American cities. Habitat International, Special Issue: Urban Segregation in Latin America 54, Part 1, pp. 3-9. https://doi.org/10.1016/j. habitatint.2015.08.012

Gold, R, (1970). Urban Violence and Contemporary Defensive Cities. Journal of the American Institute of Planners 36, pp. 146-159. https://doi.org/10.1080/01944367008977301

Grillo, I, (2013). El Narco: The Bloody Rise of Mexican Drug Cartels. Bloomsbury Paperbacks, London.

Hagan, F, (2012). Introduction to Criminology: Theories, Methods, and Criminal Behavior, Eighth Edition edition. ed. SAGE Publications, Inc, Los Angeles.

Hernandez, A., 2013. Narcoland: The Mexican Drug Lords And Their Godfathers, ed. Verso, London.

Hita, C. and Sanchez, L. 2013. Socio-Spatial Inequality and Violence. Sociology Mind 3(4), 298-303. doi:10.4236/sm.2013.34040 
Howard, D, Hume, M, Oslender, U, (2007). Violence, fear, and development in Latin America: a critical overview. Development in Practice 17, pp. 713-724. https://doi.org/10.1080/09614520701628071

Imbusch, P, Misse, M, Carrión, F, (2011). Violence Research in Latin America and the Caribbean: A Literature Review. International Journal of Conflict and Violence 5, pp. 87-154.

IMPLAN Culiacan, (2010). Mapa interactivo.

Jütersonke, O, Muggah, R, Rodgers, D, (2009). Gangs, Urban Violence, and Security Interventions in Central America. Security Dialogue 40, pp. 373-397. https://doi.org/10.1177/0967010609343298

Kawachi, I., Kennedy, B.P., Wilkinson, R.G., 1999. Crime: social disorganization and relative deprivation. Social Science \& Medicine 48(6), 719-731. doi:10.1016/S0277-9536(98)00400-6

Kemp, S, (2015). Ecological Framework [WWW Document]. Oxford Bibliographies. URL http://www.oxfordbibliographies.com/view/ document/obo-9780195389678/obo-9780195389678-0095.xml (accessed 11.7.15).

Latinobarometro, (2010). Database. Santiago.

Lefebvre, H., 1991. The Production of Space. Wiley. Massachusetts, USA. Lutters, W, Ackerman, M, (1996). An introduction to the Chicago School of Sociology. Interval Research Proprietary.

Massey, D., (2005). For Space, 1st edition. ed. SAGE Publications Ltd, London.

McIlwaine, C, Moser, C, (2007). Living in Fear: How the Urban Poor Perceive Violence, Fear and Insecurity, in: Fractured Cities. Social Exclusion, Urban Violence and Contested Spaces in Latin America. Zed Books Ltd, New York, pp. 117-138.

Merton, R, (1938). Social Structure and Anomie. American Sociological Review 3, p. 672. https://doi.org/10.2307/2084686

Meth, P, Malaza, K, (2010). Violent research: the ethics and emotions of doing research with women in South Africa. Ethics, Place \& Environment 6,pp. 143-159. https://doi.org/10.1080/1366879032000130786 Mexico Evalua, (2015). Prevencion del delito en Mexico: ¿Cuáles son las prioridades? México Evalúa, Centro de Análisis de Políticas Públicas, Mexico, D.F. 
Morenoff, J, Sampson, R, Raudenbush, S, (2001). Neighborhood Inequality, Collective Efficacy, and the Spatial Dynamics of Urban Violence*. Criminology 39, pp. 517-558. https://doi. org/10.1111/j.1745-9125.2001.tb00932.x

Morrison, D., (1971). Some Notes Toward Theory on Relative Deprivation, Social Movements, and Social Change. American Behavioral Scientist.

Moser, C., (2004). Urban Violence and Insecurity: An Introductory Roadmap. Environment and Urbanization 16, pp. 3-16. https://doi. org/10.1177/095624780401600220

Moser, C, Horn, P, (2011). Understanding the tipping point of urban conflict: violence, cities and poverty reduction in the developing world. Global Urban Research Centre, University of Manchester, Understanding the tipping point of urban conflict: violence, cities and pove rty reduction in the developing world Working Paper \#1.

Moser, C, McIlwaine, C, (2006). Latin American Urban Violence as a Development Concern: Towards a Framework for Violence Reduction. World Development 34, pp. 89-112. https://doi.org/10.1016/j. worlddev.2005.07.012

Muggah, R, (2014). Deconstructing the fragile city: exploring insecurity, violence and resilience. Environment and Urbanization 26, pp. 345-358. https://doi.org/10.1177/0956247814533627

Muggah, R, (2012). Researching the urban dilemma: Urbanization, poverty and violence. International Development Research Centre, IDRC, Canada.

Noroeste Redaccion, (2010). Fallece estrangulada y a golpes una mujer. Noroeste Culiacan.

Observatorio Nacional Ciudadano (ONC). (2015). Incidencia de los delitos de alto impacto en México. Observatorio Nacional Ciudadano. Seguridad, Justicia y Legalidad, México.

Organización para la Cooperación y el Desarrollo Económicos (OECD). (2016). States of Fragility 2016: Understanding violence. Organization for Economic Co-operation and Development, OECD Publishing, Paris. 
OECD, (2016). States of Fragility 2016: Understanding violence. OECD Publishing, Paris.

Pansters, W, Castillo-Berthier, H, (2007). Mexico City, in: Koonings, K., Kuijt, D. (Eds.), Fractured Cities: Social Exclusion, Urban Violence and Contested Spaces in Latin America. Zed Books, London, pp. $36-57$.

Pansters, W., 2012. Violence, Coercion, and State-Making in TwentiethCentury Mexico: The Other Half of the Centaur. Stanford, California, USA, Stanford University Press.

Pavoni, A, and Tulumello, S. (2018, p. 2) argue "urban violence (and the fear thereof) can be said to emerge out of the intersections between structures, processes, narratives, practices and bodies that constitute the urban. https://doi.org/10.1177/0309132518810432

Pedrazzini, Y, Vincent-Geslin, S, Thorer, A, (2014). Violence of Urbanization, Poor Neighbourhoods and Large-Scale Projects: Lessons from Addis Ababa, Ethiopia. Built Environment 40, pp. 394-407. https:// doi.org/10.2148/benv.40.3.394

Rodgers, D, (2010). Urban violence is not (necessarily) a way of life: towards a political economy of conflict in cities, in: Beall, J., GuhaKhasnobis, B., Kanbur, R. (Eds.), Urbanization and Development: Multidisciplinary Perspectives. Oxford University Press, Oxford, UK.

Rodgers, D, (2004). "Disembedding" the city: crime, insecurity and spatial organization in Managua, Nicaragua. Environment and Urbanization 16, pp. 113-124. https://doi.org/10.1177/095624780401600202 Rodgers, D, O’Neill, B, (2012). Infrastructural violence: Introduction to the special issue. Ethnography 13, pp. 401-412. https://doi. org/10.1177/1466138111435738

Rotker, S, Goldman, K, (2002). Citizens of Fear: Urban Violence in Latin America. Rutgers University Press.

Sabatini, F, (2006). The Social Spatial Segregation in the Cities of Latin America (Discussion Papers \& Presentations). Inter-American Development Bank.

Sanchez, M, (2006). Insecurity and Violence as a New Power Relation in Latin America. The Annals of the American Academy of Political and Social Science 606, pp. 178-195. 
Scheper-Hughes, N, Bourgois, P. (Eds.), (2003). Violence in War and Peace: An Anthology, 1 edition. Ed. Wiley-Blackwell, Malden, Mass.

Schneider, R, Kitchen, T, (2007). Crime prevention and the built environment. Routledge, London; New York.

Secretaría de Gobernación (SEGOB), y Secretariado Ejecutivo del Sistema Nacional de Seguridad Pública (SESNSP), 2013. Incidencia Delictiva del Fuero Común 2013. Secretaria de Gobernación. Secretariado Ejecutivo del Sistema Nacional de Seguridad Publica, México. Secretaría de Gobernación (SEGOB), y Secretariado Ejecutivo del Sistema Nacional de Seguridad Pública (SESNSP). (2010). Incidencia Delictiva del Fuero Común 2010. Secretaria de Gobernación. Secretariado Ejecutivo del Sistema Nacional de Seguridad Publica, México.

Secretaría de Seguridad Pública y Tránsito Municipal. (2015). Reglamento interior de la Secretaría de Seguridad Pública y Tránsito Municipal. Culiacán, Sinaloa.

SEGOB, SESNSP, 2013. Incidencia Delictiva del Fuero Común (2013). Secretaria de Gobernacion. Secretariado Ejecutivo del Sistema Nacional de Seguridad Publica, Mexico.

SEGOB, SESNSP, (2010). Incidencia Delictiva del Fuero Común 2010. Secretaria de Gobernación. Secretariado Ejecutivo del Sistema Nacional de Seguridad Publica, Mexico.

Seguridad, Justicia y Paz, (2016). La violencia en los municipios de Mexico (2015). Consejo Ciudadano para la Seguridad Publica y Justicia Penal, Mexico, D.F.

Shaw, M., (2009). Conceptual and theoretical frameworks for organised violence. International Journal of Conflict and Violence 3, pp. 97-106.

Springer, S. (2011). Violence sits in places? Cultural practice, neoliberal rationalism, and virulent imaginative geographies. Political Geography 30(2), 90-98. doi:10.1016/j.polgeo.2011.01.004

Springer, S., Le Billon, P., (2016). Violence and space: An introduction to the geographies of violence. Political Geography, SI: Violence and Space 52, pp. 1-3. https://doi.org/10.1016/j.polgeo.2016.03.003 Springer, S, (2015). Violent Orientalism: Imagining the "Savage Other," in: Springer, S. (Ed.), Violent Neoliberalism: Development, Discourse, 
and Dispossession in Cambodia. Palgrave Macmillan US, New York, pp. 61-80. https://doi.org/10.1057/9781137485335_4

Tulumello, S, (2015). From "Spaces of Fear" to "Fearscapes": Mapping for Reframing Theories About the Spatialization of Fear in Urban Space. Space and Culture. https://doi.org/10.11771206331215579716

United Nations Office on Drugs and Crime (UNODC). (2013). Global study on homicide 2013. Trends, contexts, data., United Nations publication, Sales No. 14.IV.1. United Nations Office on Drugs and Crime, Vienna.

UNODC, (2013). Global study on homicide 2013. Trends, contexts, data., United Nations publication, Sales No. 14.IV.1. United Nations Office on Drugs and Crime, Vienna.

Valdez Cárdenas, J, (2017). Malayerba: La vida bajo el narco, 2 edition. ed. Jus, Libreros y Editores.

Valdez Cárdenas, J, (2015). Huérfanos del narco: Los olvidados de la guerra del narcotráfico. Aguilar.

Valdez Cárdenas, J, (2007). Los morros del narco. Aguilar.

Valenzuela- Aguilera, A., 2013. Urban Surges: Power, Territory, and the Social Control of Space in Latin America. Latin American Perspectives 40(2), 21-34. doi:10.1177/0094582X12466834

Walker, Iain, Pettigrew, Thomas, 1984. Relative deprivation theory: An overview and conceptual critique. British Journal of Social Psychology 23, pp. 301-310. https://doi.org/10.1111/j.2044-8309.1984. tb00645.x

Ward, P, (2009). Unpackaging residential segregation: the importance of scale and informal market processes. Investigaciones Geográficas, Boletín del Instituto de Geografía, UNAM, pp. 114-134.

Winton, A, (2005). Youth, gangs and violence: Analysing the social and spatial mobility of young people in Guatemala City. Children's Geographies 3, pp. 167-184. https://doi.org/10.1080/14733280500161537

Winton, A, (2004). Urban violence: a guide to the literature. Environment and Urbanization 16, pp. 165-184. https://doi. org/10.1177/095624780401600208

World Bank, (2011). Violence in the City: Understanding and Supporting Community Responses to Urban Violence. World Bank, Social Development Department, Conflict and Crime and Violence Team. 
Violencia e inseguridad en el espacio urbano: un enfoque analítico basado en el marco ecológico para la violencia.

World Health Organisation, (2016). The ecological framework [WWW Document]. Violence prevention approach. URL http://www.who. int/violenceprevention/approach/ecology/en/ (accessed 11.7.16).

\section{Annex 1}

Semi-structured interviews details with community members in 5 de Febrero

\begin{tabular}{|c|c|c|c|c|c|}
\hline No. & Pseudonym & Location & Age & Sex & Details \\
\hline 1 & Diana & $\begin{array}{l}5 \text { de Febrero, } \\
\text { Culiacan }\end{array}$ & 48 & $\mathrm{~F}$ & $\begin{array}{l}\text { Conducted work as programme } \\
\text { coordinator in } 5 \text { de Febrero }\end{array}$ \\
\hline 2 & Juan & $\begin{array}{l}5 \text { de Febrero, } \\
\text { Culiacan }\end{array}$ & 52 & M & $\begin{array}{l}\text { Works as a security night } \\
\text { watchman }\end{array}$ \\
\hline 3 & Jose & $\begin{array}{l}5 \text { de Febrero, } \\
\text { Culiacan }\end{array}$ & 49 & M & 5 de Febrero community leader \\
\hline 4 & Lety & $\begin{array}{l}5 \text { de Febrero, } \\
\text { Culiacan }\end{array}$ & 28 & $\mathrm{~F}$ & $\begin{array}{l}\text { NGO Culiacan Participa Wor- } \\
\text { king in } 5 \text { de Febrero }\end{array}$ \\
\hline 5 & Nadia & $\begin{array}{l}5 \text { de Febrero, } \\
\text { Culiacan }\end{array}$ & 32 & $\mathrm{~F}$ & $\begin{array}{l}\text { NGO Circo Volador Working in } \\
5 \text { de Febrero }\end{array}$ \\
\hline 6 & Aleyda & $\begin{array}{c}5 \text { de Febrero, } \\
\text { Culiacan }\end{array}$ & 36 & $\mathrm{~F}$ & Director DIF 5 de Febrero \\
\hline 7 & Caro & $\begin{array}{l}5 \text { de Febrero, } \\
\text { Culiacan }\end{array}$ & 68 & $\mathrm{~F}$ & Former community leader \\
\hline 8 & $\begin{array}{l}\text { Profesor } \\
\text { Antonio }\end{array}$ & $\begin{array}{l}5 \text { de Febrero, } \\
\text { Culiacan }\end{array}$ & 49 & M & $\begin{array}{l}\text { Director of elementary school } \\
\text { in the colonia }\end{array}$ \\
\hline 9 & Baldovino & $\begin{array}{l}5 \text { de Febrero, } \\
\text { Culiacan }\end{array}$ & 52 & M & Legal department CESAVVI \\
\hline
\end{tabular}




\section{Annex 2 Age and gender of respondents' survey sample in Colo- nia 5 de Febrero.}

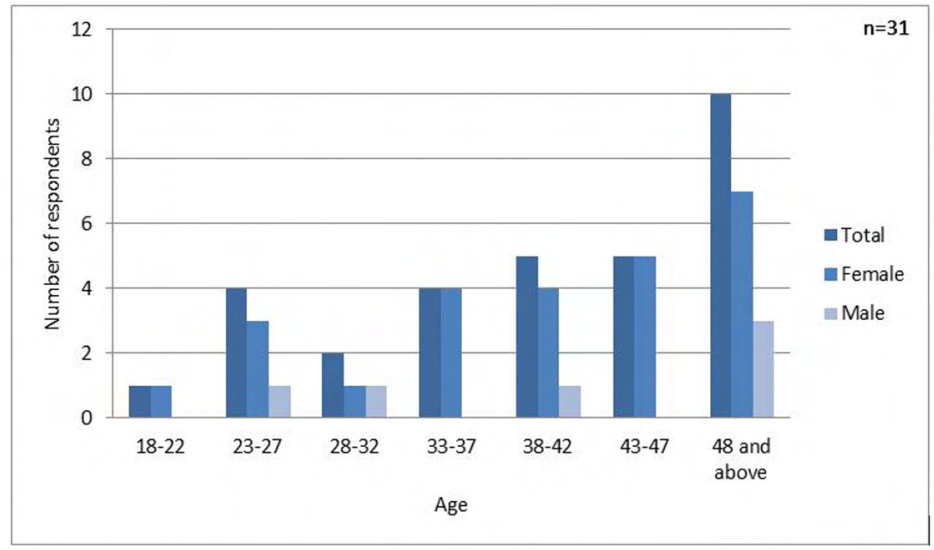

Source: author, based on surveys from fieldwork 2015. 